\title{
Impact of a teacher development programme on approaches to teaching in higher education
}

\section{González-Geraldo, José L. ${ }^{a}$; Monroy, Fuensanta ${ }^{\text {b }}$}

${ }^{\mathrm{a} D e p a r t m e n t}$ of Pedagogy, University of Castilla-La Mancha, Spain. ${ }^{\mathrm{b}}$ Department of Research Methods in Education, University of Murcia, Spain.

\begin{abstract}
The Bologna process involved a strategic change that included in its policy agenda a move towards a student-centred scenario. In addition, a reasonable association may be assumed to exist between teaching development programmes and student learning outcomes. This research study focused on the impact that a brief yet intense formal and non-qualifying teaching programme, delivered as a seminar and supported by the University of Castilla-La Mancha (UCLM) in Spain, had on teachers' approaches to teaching measured by the most recent Spanish adaptation of the Approaches to Teaching Inventory (S-ATI-20). Results showed that there was a positive and statistically significant impact of the training programme on approaches to teaching measured by the information transmission/teacher-focused scale (ITTF). Poor attendance rate to this non-compulsory programme, course duration, participant profile, psychometric structure of the questionnaire used, and the relationship between teaching development programmes and approaches to teaching are discussed.
\end{abstract}

Keywords: Teacher development programme; teacher training; approaches to teaching; teaching approaches; higher education. 


\section{Introduction}

For the last decades there has been an increasing interest in the quality of teacher training at European universities, an interest fostered yet not originated by the creation of the European Higher Education Area (EHEA) and the well-known Bologna process. The Bologna process involved a strategic change that included in its policy agenda a move towards a student-centred scenario characterized by innovative teaching methods that should involve students as active participants in their own learning (Bucharest Communiqué, 2012) and where knowledge, skills and competences are keystones for holistic learning outcomes (Yerevan Communiqué, 2015) .

Research has shown that there is a direct relationship between teaching programmes and approaches to teaching (e.g., Gibbs \& Coffey, 2004), and between teachers' approaches to teaching and students' approaches to learning (e.g., Trigwell et al., 1999). Therefore, a reasonable, though indirect, association may be assumed to exist between teaching development programmes and student learning outcomes (Prebble et al., 2004), which would match the EHEA objectives mentioned earlier.

Learning to teach in higher education is not a straightforward path. In fact, teaching may be one of the last "non-professions" (Baume, 2006). In most of Europe and other developed economies, university teachers are not required to obtain teaching qualification (Parsons et al., 2010) and Spain is not an exception (Zabalza, 2009). Thus, it is not rare to find an array of compulsory and non-compulsory teaching programmes offered by organizations (from universities to governments) with a variety of pedagogical or domain specific contents and aims. Nevertheless, "formal [sic.], sometimes mandatory, but non-qualification approaches have dominated most institutional and other arrangements, and developed under different strategic and funding stimuli" (Parsons et al. 2012, p. 7).

This research study focused on the impact that a brief yet intense formal and non-qualifying teaching programme, delivered as a seminar and supported by the University of Castilla-La Mancha (UCLM) in Spain, had on the approaches to teaching of the UCLM teachers who voluntarily participated in it. The authors were aware of the fact that there may be other sources of impact which should be explored, such as departments or institutions (Hanbury et al., 2008), yet these were not included at this stage in this study.

Teachers' approaches to teaching is a theoretical framework derived from the Students' Approaches to Learning tradition (SAL) based on the work of the Göteborg group led by Marton (1976). Years later, a more quantitative stream introduced the use of questionnaires to monitor students' approaches to learning (e.g., Biggs, 1979; Entwistle et al., 1979) and teachers' approaches to teaching (e.g., Trigwell \& Prosser, 1996). Although there is a widespread misunderstanding of Marton and Säljö's initial findings (1976a, 1976b) and even a convenient but inaccurate reuse of phenomenographic methodology (see 
Richardson, 2015), SAL is a sound theoretical background that, among other possibilities, would allow monitoring if teachers show a predominant Information Transmission/Teacher-Focused approach (ITTF) or, on the contrary, a Conceptual Change/Student-Focused approach (CCSF) (see Monroy et al., 2015), which would be in line with the premises set by the EHEA.

Our hypothesis was that well-designed teacher development programmes might have at least some impact on participants' approaches to teaching since approaches are contextdependent and not as stable as conceptions of teaching, even though both conceptions and approaches are related (Lam \& Kember, 2006; Trigwell et al., 1999; Trigwell \& Prosser, 1996). Thus, upon implementing a teacher development programme, three scenarios might be possible: 1) a decrease in participants' ITTF score, 2) an increase in participants' CCSF score, and 3) an improvement in both approaches (i.e. a simultaneous decrease of ITTF and increase of CCSF).

\section{Method}

\subsection{Design}

This research study used a pretest-posttest pre-experimental design with no control group.

\subsection{Participants}

The data were collected during three consecutive academic years (2014-15, 2015-16, 20162017) which allowed gathering an overall sample of $N=85$, which was selected nonrandomly. Of those participants, $75 \%(n=64)$ returned the questionnaire administered at pretest and posttest, while $20 \%$ completed only the pretest $(n=17)$ and $4.7 \%(n=4)$ only the posttest. All participants attended the programme voluntarily.

In terms of academic years, the distribution was as follows: $n=48$ (2014-15), $n=22$ (201516), and $n=15$ (2016-17). Differences in the number of participants may be explained by the fact that the development programme was run on various occasions during the course of implementation, namely: three times along 2014-15, twice in 2015-16, and one in this academic year (2016-17) — it is expected that the course may be offered again in the second semester of 2016-17. It is worth noting that the sample might have been larger had the UCLM not cancelled three editions in which less than ten teachers had registered.

In terms of gender, the sample was biased as $63.6 \%$ was female teachers (36.4\% was male). The median age was 42 years old $(S D=9)$. More than half of the sample $(56.6 \%)$ reported having had some kind of teacher training along their career as teachers. Finally, the teaching experience of participants was recorded as shown in Table 1. 
Table 1

Teaching experience of the sample in years

\begin{tabular}{cccc}
\hline & $\mathrm{n}$ & $\%$ & accum. $\%$ \\
\hline None & 4 & 4.7 & 4.7 \\
$<5$ & 16 & 18.8 & 23.5 \\
$6-10$ & 13 & 15.3 & 38.8 \\
$11-20$ & 27 & 31.8 & 70.6 \\
$>21$ & 25 & 29.4 & 100 \\
\hline
\end{tabular}

\subsection{Procedure and instrument}

The teaching programme was entitled "Educating at university: Keys to success" and was offered free of charge as part of the strategic training plan for the UCLM academic staff along other forty courses on teaching and non-teaching competences such as the use of ICT. This 20-hour programme focused on general pedagogical contents and methodologies (e.g., Problem-Based Learning, Reflexive Thinking, and Cooperative Learning) with a particular emphasis on assessment (Constructive Alignment). It was taught on one day for two consecutive weeks by three members of the Department of Pedagogy in different cities because the UCLM is a multicampus university. Between the two seminar days there were online tasks for participants to practise and consolidate learnt contents. At the end of the seminar and as an institutional requirement to pass the course, all participants completed a "happy sheet" satisfaction instrument, which is one of the most widely spread and prevalent ways to evaluate teacher development programmes (Chalmers \& Gardiner, 2015).

In addition to this mandatory evaluation instrument and among other assessment tools, participants were asked to fill out the S-ATI-20 (see Monroy et al., 2015; Monroy \& González-Geraldo, 2017) both before and after the seminar. Apart from minimum details, no further information about the aims and scope of this study were given to the participants.

The S-ATI-20 is a Spanish version of the Approaches to Teaching Inventory derived from a combination of the 16-item and 22-item versions developed by Trigwell \& Prosser (2004) and Trigwell et al., (2005) respectively. The S-ATI-20 has 20 items which represent the two main dimensions identified in the literature: Information Transmission/Teacher-Focused (ITTF, 10 items) and Conceptual Change/Student-Focused (CCSF, 10 items).

\subsection{Data analysis}

Data collected via the S-ATI-20 were analyzed with IBM SPSS statistical package v. 22. Because of the novelty of this instrument in its adapted version to the Spanish context, a forced exploratory factor analysis (Maximum Likelihood with oblique rotation) was conducted. In addition, reliability with Cronbach's alpha was calculated separately on the 
pretest and posttest datasets in order to measure the psychometric properties of the instrument. Then, a related measures $t$-test was conducted to test our hypothesis.

\section{Results}

The results of the exploratory factor analysis supported the expected two factors structure of the S-ATI-20 found in previous studies (e.g., Monroy et al., 2015; Monroy \& GonzálezGeraldo, 2017). However, at posttest (35.2\% of the explained variance) the results were clearer than at pretest $(30.9 \%)$ as some items had low loading scores (e.g., item 4 at ITTF: .159), or loaded on the two factors simultaneously (item 6 at ITTF: .219; and at CCSF: .279). Reliability coefficients at ITTF (pretest: $\alpha=.648$; posttest: $\alpha=.757$ ) were lower than at CCSF (pretest: $\alpha=.749$; posttest: $\alpha=.774$ ), which match the results of studies with previous versions of the ATI (e.g., Hanbury et al., 2008; Prosser \& Trigwell, 2006).

The results of mean comparison (Table 2) are shown following the pattern of the work of Hanbury et al. (2008) who also used the ATI (Trigwell \& Prosser, 2004) but the 22-item version.

Table 2

Summary of ATI mean scores at pretest and posttest

\begin{tabular}{lcccc}
\hline Scale & Mean pretest & Mean posttest & $p$ & Effect size \\
\hline CCSF & 3.95 & 4.00 & .407 & .11 \\
ITTF & 3.10 & 2.95 & .009 & .32 \\
\hline
\end{tabular}

There was a positive, non-significant increase in the CCSF score and a significant decrease in the ITTF score with a medium effect size $(t[63]=2.709, p=.009, r=.32)$. If each academic year was analyzed separately, the expected changes could still be identified (i.e. lower ITTF and higher CCSF at posttest) although statistically non-significant in any case. However, in this last case and because of the small size of the subsamples (per academic year), results must be taken with caution.

\section{Discussion}

Apart from the relative impact of the development programme, the most striking finding of this research study is the poor attendance rate. The UCLM employs more than 2,300 teachers (both part-time and full-time), and it is all the more worrying that only 85 teachers in three years were motivated enough to take on a course that would improve their teaching competences and thus potentially make them better professionals. It is true that not all teachers interested in the course had the possibility to actually complete it, as the programme was cancelled when there were less than ten registrees. Moreover, teachers had 
to choose from an array of twenty programmes offered by the university, so it is likely that most teaching staff regarded a course titled "Educating at university: Keys to success" as a low-priority action. The fact that two thirds of the sample were women is an indicator that female teachers were more interested in what "education" is about at university. Finally, such an aloofness about teaching matters is likely not a coincidence in an academic world where the "Publish or Perish" leitmotiv, and even a more conspicuous "Share or Shame" motto (González-Geraldo, 2015), allows little room and time for non-research duties. Future lines should focus on examining the reasons for poor attendance rate to teacher training courses, as well as the meaning of the modest impact of such programmes.

Another interesting feature is that over half of participants reported having more than ten years of teaching experience, so the question arises as to whether junior teachers lack interest or do not believe in this type of teaching courses. Available time and future expectations regarding promotion are also against improving teaching competences at initial stages of an academic career. Thus, the classical saying Primum vivere, deinde philosophari could become "first research, then pedagogy".

The results from this study support the two-factor structure of the instrument (ATI) posited in previous research. It is worth noting the use of a factorial procedure different from the "Little Jiffy" (i.e. principal components analysis with varimax rotation and eigenvalues greater than 1.0) originally used in the development of the ATI and typically applied in subsequent studies with factor analysis (see Meyer, \& Eley, 2006). Nevertheless, future studies using the S-ATI-20 should revise the wording of some items, such as item no. 2, as one participant noted it was too long and difficult to understand.

Far from intending to generalize results, this study puts forward the importance of conducting teacher development programmes aimed at faculty, even if courses are short and of a durantion below one year as recommended by previous research (see Parsons et al., 2012) The findings reveal that attitudes may change through a development programme, so the question remains as to whether such attitudinal changes would materialize in observable behaviour that could really make a difference in the classroom. Despite the fact the development programme was short, it is good news that changes are noticeable in such a short term. However, bearing in mind that the sample was different each year, we should remark that statistical changes were observed only after three academic years. Further research ought to focus on whether changes last in the mid-term and if they result in a better students' learning processes and outcomes. Nevertheless, any impact on teachers tends to flourish after an incubation period and it is unusual to detect changes as quickly as those found in this study. 
This study shows a positive relationship between teaching development programmes and approaches to teaching. The results may be of interest to university teachers wishing to improve their teaching competences and their students' learning outcomes, as well as to university administrators interested in the quality of universities from a teaching perspective.

\section{References}

Baume, D. (2006). Towards the End of the Last Non-Professions? International Journal for Academic Development, 11(1), 57-60.

Biggs, J. (1979). Individual differences in study processes and the quality of learning outcomes. Higher Education, 8, 381-394.

Bucharest Communiqué. (2012). Making the Most of Our Potential: Consolidating the European Higher Education Area. Retrieved from http://www.ehea.info/uploads/(1)/bucharest communique 2012(1).pdf

Chalmers, D., \& Gardiner, D. (2015). An evaluation framework for identifying the effectiveness and impact of academic teacher development programmes. Studies in Educational Evaluation [still in press]

Entwistle, N. J., Hanley, M., \& Hounsell, D. (1979). Identifying distinctive approaches to studying. Higher Education, 8, 365-380.

Gibbs, G., \& Coffey, M. (2004). The impact of training of university teachers on their teaching skills, their approach to teaching and the approach to learning of their students. Active Learning in Higher Education, 5(1), 87-100.

González-Geraldo, J. L. (2015). Publicar ya no es suficiente: los peligros del panóptico digital en un mundo académico excesivamente transparente. In J. L. González-Geraldo (Coord.), Educación, Desarrollo y Cohesión Social (pp. 413-418). Cuenca: Servicio de Publicaciones de la Universidad de Castilla-La Mancha.

Hanbury, A., Prosser, M., \& Rickinson, M. (2008). The differential impact of UK accredited teaching development programmes on academics'approaches to teaching. Studies in Higher Education, 33(4), 469-483.

Lam, B. H., \& Kember, D. (2006). The relationship between conceptions of teaching and approaches to teaching. Teachers and Teaching, 12(6), 693-713.

Marton, F. (1976). What does it take to learn? Some implications of an alternative view of learning. In N. J. Entwistle (Ed.), Strategies for Research and Development in Higher Education (pp. 32-43). Amsterdam: Swets and Zeitlinger.

Marton, F., \& Säljö, R. (1976a). On qualitative differences in learning I - Outcome and Process. British Journal of Educational Psychology, 46, 4-11.

Marton, F., \& Säljö, R. (1976b). On qualitative differences in learning: II — Outcome as a function of the learner's conception of the task. British Journal of Educational Psychology, 46, 115-127. 
Meyer, J. H. F., \& Eley, M. G. (2006). The Approaches to Teaching Inventory: A critique of its development and applicability. British Journal of Educational Psychology, 76(3), 633-649.

Monroy, F., \& González-Geraldo, J. L. (2017). Teaching conceptions and approaches: Do qualitative results support survey data? Revista de Investigación Educativa. 35(1), $167-$ 180.

Monroy, F., González-Geraldo, J. L., \& Hernández-Pina, F. (2015). A psychometric analysis of the Approaches to Teaching Inventory (ATI) and a proposal for a Spanish version (S-ATI-20). Anales de Psicología, 31(1), 172-183.

Parsons, D. J., Hill, I., Holland, J., \& Willis, D. (2012). Impact of teaching development programmes in higher education. York: Higher Education Academy (HEA).

Parsons, D. J., Hughes, J., \& Walsh, K. (2010). Initial Training and Professional Development of Teachers and Trainers beyond Upper-secondary Education. Publications Office of the European Union, Cedefop.

Prebble, T., Hargraves, H., Leach, L., Naidoo, K., Suddaby, G., \& Zepke, N. (2004). Impact of student support services and academic development programmes on student outcomes in undergraduate tertiary study: A synthesis of the research. New Zeland: A Report to the Ministry of Education.

Richardson, J. T. E. (2015). Approaches to learning or levels of processing: What did Marton and Säljö (1976a) really say? The legacy of the work of the Göteborg group in the 1970s. Interchange, 46, 239-269.

Trigwell, K., \& Prosser, M. (1996). Changing approaches to teaching: A relational perspective. Studies in Higher Education, 21(3), 275-284.

Trigwell, K., \& Prosser, M. (2004). Development and use of the Approaches to Teaching Inventory. Educational Psychology Review, 16(4), 409-424.

Trigwell, K., Prosser, M., \& Waterhouse, F. (1999). Relations between teachers' approaches to teaching and students' approaches to learning. Higher Education, 37(1), 57-70.

Trigwell, K., Prosser, M., \& Ginns, P. (2005). Phenomenographic pedagogy and a revised Approaches to Teaching Inventory. Higher Education Research \& Development, 24(4), 349-360.

Yerevan Communiqué. (2015). EHEA Ministerial Conference. Retrieved from http://bologna-yerevan2015.ehea.info/files/YerevanCommuniqueFinal.pdf

Zabalza, M. A. (2009). Ser profesor universitario hoy. La Cuestión universitaria, 5, 68-80. 